\title{
MEWUJUDKAN KETERAMPILAN 4C SISWA DI ABAD 21 MELALUI MODEL PEMBELAJARAN BERBASIS MASALAH
}

\author{
Romein Armando \\ Email: 18101111310014@mhs.ulm.ac.id \\ Program Studi Pendidikan Sejarah Fakultas Keguruan dan Ilmu Pendidikan \\ Universitas Lambung Mangkurat \\ Banjarmasin
}

\begin{abstract}
Sejatinya dunia pendidikan dan pembelajaran berkembang dengan seiring perubahan zaman. Di abad 21 ini, pembelajaran tidak hanya berpusat pada kognitif dan siswa hanya menghafal tetapi di era revolusi industri 4.0 ini siswa dituntut harus mampu bersaing dengan negara-negara lain melalui keterampilan berpikir kreatif (creative thinking), berpikir kritis dan pemecahan masalah (critical thinking and problem solving), berkomunikasi (communication), dan berkolaborasi (collaboration) atau yang biasa disebut dengan 4C. Salah satu model pembelajaran yang dapat mengasah keterampilan siswa adalah pembelajaran berbasis masalah adalah pendekatan pembelajaran dengan mengorientasikan siswa pada masalah kontekstual, yang mendorong siswa untuk mampu menemukan masalahnya, menelaah kuantitas, kualitas dan kompleksitas masalah yang diajukan. Terlebih dalam pembelajaran sejarah metode pembelajaran berbasis masalah dapat digunakan guna menarik minat siswa dan menambah semangat patriotisme siswa.
\end{abstract}

Kata Kunci : keterampilan 4c , siswa, Abad 21, Model Pembelajaran, Sejarah, Berbasis Masalah, 


\section{PENDAHULUAN}

Perkembangan teknologi sangat mempengaruhi kehidupan setiap manusia didunia dari berbagai aspek mulai dari kesehatan, kecantikan, industri termasuk pendidikan. Hal ini berdampak pada wajah pendidikan yang kini telah mengalami banyak perubahan seiring dengan perkembangan teknologi ini. Media ajar, model pembelajaran, hingga profil guru dan siswa di era yang kini dikenal sebagai era revolusi industri 4.0 jauh berbeda dengan era-era sebelumnya dan semua itu tidak lepas dari pengaruh teknologi yang seakan telah menjadi nafas kehidupan manusia saat ini. Akibat dari revolusi industri ini adalah munculnya reformasi dalam pendidikan, yakni penggunanaan teknologi informasi dan komunikasi (Sugiarti dan Kurniawati, 2019).

Pendidikan merupakan sarana terpenting untuk mewujudkan kemajuan bangsa dan negara. Dengan pendidikan yang bermutu, akan tercipta sumber daya manusia yang berkualitas. Salah satu persoalan besar yang dihadapi bangsa Indonesia saat ini adalah rendahnya kualitas pendidikan nasional. Kualitas pendidikan ini harus diperbaharui dengan inovasi dan kreativitas dalam komponen-komponen pendidikan. Komponen-komponen pendidikan meliputi guru, siswa, kurikulum, alat (media pembelajaran) dan sumber belajar, materi, metode maupun alat evaluasi saling bekerjasama untuk mewujudkan proses belajar yang kondusif (Handayani dan Sapir, 2009).

Sejauh ini proses pembelajaran di sekolah masih didominasi oleh sebuah paradigma yang menyatakan bahwa sebuah pengetahuan (knowledge) merupakan perangkat fakta-fakta yang harus dihafal. Di samping itu, situasi kelas sebagian besar masih berfokus pada guru (teacher) sebagai sumber utama pengetahuan, serta penggunaan metode ceramah sebagai pilihan utama strategi belajar mengajar (Handayani dan Sapir, 2009). Hal ini sesuai dengan fakta bahwa mayoritas proses belajar mengajar di Indonesia masih menggunakan metode konvensional yaitu masih terbatas pada teacher oriented. Teacher oriented ini tidak akan mampu membuat siswa menjadi berkembang dan tidak siap menghadapi ilmu dan teknologi yang berkembang sangat pesat. Untuk itu, pada abad 21 ini, sekolah dituntut untuk memiliki keterampilan berpikir kreatif (creative thinking), berpikir kritis dan pemecahan masalah (critical thinking and problem solving), berkomunikasi (communication), dan berkolaborasi (collaboration) atau yang biasa disebut dengan 4C. Dengan 
keterampilan 4C ini maka diharapkan siswa memiliki kemampuan hard skill maupun soft skill dalam pembelajaran dan siap berkompetisi.

Salah satu cara guru dalam menciptakan siswa yang mampu memiliki keterampilan 4C salah satunya adalah dengan metode pembelajaran yang mampu membentuk keterampilan $4 \mathrm{C}$ siswa.

\section{METODE PEMBELAJARAN BERBASIS MASALAH}

Salah satu yang dapat dilakukan memperbaiki proses pembelajaran dan mengoptimalkan kemampuan kreativitas, pemecahan masalah, komunikasi dan kolaborasi siswa adalah dengan melaksanakan model pembelajaran yang mampu diterapkan guru bagi siswa adalah pembelajaran berbasis masalah.

Pembelajaran berbasis masalah memberikan dorongan kepada peserta didik untuk tidak hanya sekedar berpikir sesuai yang bersifat konkret, tetapi lebih dari itu berpikir terhadap ide-ide yang abstrak dan kompleks. Dengan kata lain, pembelajaran berbasis masalah melatih peserta didik untuk memiliki keterampilan berpikir tingkat tinggi.

Pembelajaran berbasis masalah adalah pendekatan pembelajaran dengan mengorientasikan siswa pada masalah kontekstual, yang mendorong siswa untuk mampu menemukan masalahnya, menelaah kuantitas, kualitas dan kompleksitas masalah yang diajukan (Rusman, 2010). Dengan kata lain pembelajaran berbasis masalah tidak mengharapkan siswa hanya sekedar mendengarkan, mencatat kemudian menghafal materi pelajaran, akan tetapi siswa aktif berpikir, berkomunikasi, mencari dan mengolah data, dan akhirnya menyimpulkan. Pembelajaran berbasis masalah dapat diartikan sebagai cara penyajian bahan pelajaran dengan menjadikan masalah sebagai titik tolak pembahasan untuk dianalisis dan disintesis dalam usaha mencari pemecahan atau jawaban oleh siswa itu sendiri.

Karakteristik pembelajaran berbasis masalah adalah sebagai berikut:

1. Permasalahan menjadi starting point dalam belajar;

2. Permasalahan yang diangkat adalah permasalahan yang ada didunia nyata yang tidak terstuktur; 
3. Permasalahan membutuhkan perspektif ganda (multiple perspective);

4. Permasalahan, menantang pengetahuan yang dimiliki oleh siswa, sikap, dan kompetensi yang kemudian membutuhkan identifikasi kebutuhan belajar dan bidang baru dalam belajar;

5. Belajar pengarahan diri menjadi hal yang utama;

6. Pemanfaatan sumber pengetahuan yang beragam, penggunaannya, dan evaluasi sumber informasi merupakan proses yang esensial dalam pembelajaran berbasis masalah;

7. Belajar adalah kolaboratif, komunikasi, dan kooperatif,

8. Pengembangan keterampilan inquiry dan pemecahan masalah sama pentingnya dengan penguasaan isi pengetahuan untuk mencari solusi dari sebuah permasalahan;

9. Keterbukaan proses pembelajaran berbasis masalah meliputi sintesis dan integrase dari sebuah proses belajar; dan

10. Pembelajaran berbasis masalah melibatkan evaluasi dan review pengalaman siswa dan proses belajar (Rusman, 2010).

Guru sebagai fasilitator siswa dalam pembelajaran berbasis masalah harus mengemukakan tahap-tahap dalam pembelajaran berbasis masalah sebagai berikut:

1. Orientasi siswa pada masalah;

2. Mengorganisasi siswa untuk belajar;

3. Membimbing penyelidikan individual maupun kelompok;

4. Mengembangkan dan menyajikan hasil karya; dan

5. Menganalisis dan mengevaluasi proses pemecahan masalah (Handayani dan Sapir, 2009).

\section{PERAN GURU DALAM PEMBELAJARAN BERBASIS MASALAH}

Dalam proses pembelajaran berbasis masalah komponen-komponen pembelajaran ahrus dapat berperan sesuai dengan porsinya salah satunya adalah guru. Guru merupakan orang yang berperan dalam keberhasilan proses pembelajran karena guru sebagai fasilitator yang harus memfasilitasi siswa terlebih saat pertama kali melakukan proses pembelajran. Guru harus menggunakan proses pembelajaran yang akan menggerakkan siswa menuju kemandirian, kehidupan yang lebih luas, dan belajar sepanjang hayat (long life education). Lingkungan belajar 
yang dibangun guru harus mendorong cara berpikir kritis, dan cara berpikir yang berdayaguna. Peran guru dalam pembelajaran berbasis masalah berbedan dengan peran guru didalam kelas. Guru dalam pembelajaran berbasis masalah harus memusatkan diri tentang beberapa hal yaitu;

1. Memfasilitasi proses pembelajaran berbasis masalah; mengubah cara berpikir, mengembangkan keterampilan inquiry, menggunakan pembelajaran kooperatif;

2. Melatih siswa tentang strategi pemecahan masala; pemberian alas an yang mendalam, metakognisi, berpikir kritis, dan berpikir secara sistem; dan

3. Menjadi perantara proses penguasaan informasi; meneliti lingkungan informasi, mengakses sumber informasi yang beragam, dan mengadakan koneksi (Rusman, 2010).

\section{KELEBIHAN DAN KEKURANGAN PEMBELAJARAN BERBASIS MASALAH}

Dalam setiap model pembelajaran disekolah memiliki kelebihan dan kekurangan. Kelebihan dan kekurangan ini nantinya akan menjadi evaluasi bagi tenaga pendidik yang menerapkan model pembelajaran berbasis masalah ini untuk menilai model pembelajaran ini cocok atau tidak bagi siswanya.

Pembelajaran berbasis masalah memiliki beberapa unggulan menurut Trianto, 2009 diantaranya:

1) Realistic dengan kehidupan siswa,

2) Konsep sesuai dengan kebutuhan siswa,

3) Memupuk sifat inquiry siswa,

4) Retensi konsep jadi kuat, dan

5) Memupuk kemampuan Problem Solving (pemecahan masalah).

Kelemahan pembelajaran berbasis masalah menurut Sanjaya, 2008:

1. Manakala siswa tidak memiliki minat atau tidak mempunyai kepercayaan bahwa masalah yang dipelajari sulit untuk dipecahkan, maka mereka akan merasa enggan untuk mencobanya,

2. Membutuhkan cukup waktu untuk persiapan pembelajaran (Sari dan Rihadi, 2014). 


\section{PENERAPAN PEMBELAJARAN BERBASIS MASALAH DALAM PENDIDIKAN SEJARAH}

Pembelajaran berbasis masalah merupakan model pembelajaran yang dapat digunakan dalam berbagai mata pelajaran disekolah, salah satunya adalah sejarah.

Menurut Kuntowijoyo 1995, sejarah adalah rekonstruksi masa lampau yang mempunyai makna sosial. Rekonstruksi itu meliputi apa saja yang sudah di pikirkan,di katakan,dikerjakan,dirasakan dan dialami oleh umat manusia (Anis, 2015).

Pembelajaran sejarah dijumpai ada siswa yang duduk dibangku Sekolah Menengah Atas, namun sering kali pembelajaran sejarah kurang menarik para minat siswa seperti menurut Anis, 2016 pembelajaran sejarah dianggap tidak menarik dan membosankan. Realitas ini membuat pembelajaran sejarah dianggap kurang bermakna dalam kehidupan sehari-hari yang tengah berada di tengah berada di tengah kehidupan masyarakat cenderung materalistik -konsumtif -hedonistik. Padahal tujuan pembelajaran sejarah pada tataran SMA adalah untuk mngembangkan kemampuan berpikir kritis dan kreatif, mengembangkan rasa ingin tahu inspirasi dan aspirasi, mengembangkan kemampuan mencari,mengolah,mengemas dan komunikasikan informasi dan tentunya mengembangkan semangat kebangsaan.

Karena hal itu pembelajaran sejarah perlu dibungkus dalam model pembelajaran yang dapat menarik minat siswa untuk lebih menyenangi dan merasa tertantang dalam pembelajaran sejarah yaitu dengan model pembelajaran berbasis masalah.

Dalam pembelajaran berbasis masalah dalam pembelajaran sejarah, guru dapat menyediakan berbagai macam topik pelajaran sejarah dan memfasilitasi siswa untuk dapat menggali informasi dari topik yang tersedia, hal itu dapat melatih siswa dalam berpikir kritis, kreatif dan untuk saling bertukar informasi dengan teman-teman lain dapat melatih kolaborasi dan komunikasi siswa. Selain melatih keterampilan $4 \mathrm{C}$ pada siswa, pembelajaran sejarah juga dapat memupuk semangat patriotisme. Patriotisme bukan isu politik atau gimik dan tidak sekadar semangat sematamata tetapi ia merupakan suatu perkara yang bersifat spiritual, rasa kecintaan 
yang kekal dan tebal kepada negara yang merangkum nilai kesungguhan, keyakinan, keberanian dan kesinambungan (Anis, 2017).

Pembelajaran berbasis masalah membantu siswa dalam melatih keterampilan siswa dalam 4C khususnya dalam pembelajaran sejarah. Siswa dapat memiliki daya saing, dan keterampilan 4C dalam era revolusi industri ini. 


\section{KESIMPULAN}

Pendidikan merupakan sarana terpenting untuk mewujudkan kemajuan bangsa dan negara. proses pembelajaran di sekolah masih didominasi oleh sebuah paradigma yang menyatakan bahwa sebuah pengetahuan (knowledge) merupakan perangkat fakta-fakta yang harus dihafal. Di samping itu, situasi kelas sebagian besar masih berfokus pada guru (teacher) sebagai sumber utama pengetahuan, serta penggunaan metode ceramah sebagai pilihan utama strategi belajar mengajar.

Pada abad 21 ini, sekolah dituntut untuk memiliki keterampilan berpikir kreatif (creative thinking), berpikir kritis dan pemecahan masalah (critical thinking and problem solving), berkomunikasi (communication), dan berkolaborasi (collaboration) atau yang biasa disebut dengan 4C. Dengan keterampilan 4C ini maka diharapkan siswa memiliki kemampuan hard skill maupun soft skill dalam pembelajaran dan siap berkompetisi.

Salah satu metode pembelajaran yang mampu menambah keterampilan 4C adalah permasalahan berbasis masalah.

Pembelajaran berbasis masalah adalah pendekatan pembelajaran dengan mengorientasikan siswa pada masalah kontekstual, yang mendorong siswa untuk mampu menemukan masalahnya, menelaah kuantitas, kualitas dan kompleksitas masalah yang diajukan.Dengan kata lain pembelajaran berbasis masalah tidak mengharapkan siswa hanya sekedar mendengarkan, mencatat kemudian menghafal materi pelajaran, akan tetapi siswa aktif berpikir, berkomunikasi, mencari dan mengolah data, dan akhirnya menyimpulkan.

Dalam proses pembelajaran berbasis masalah komponen-komponen pembelajaran ahrus dapat berperan sesuai dengan porsinya salah satunya adalah guru. Guru merupakan orang yang berperan dalam keberhasilan proses pembelajran karena guru sebagai fasilitator yang harus memfasilitasi siswa terlebih saat pertama kali melakukan proses pembelajran.

Guru dalam pembelajaran berbasis masalah harus memusatkan diri tentang beberapa hal yaitu;

1. Memfasilitasi proses pembelajaran berbasis masalah; mengubah cara berpikir, mengembangkan keterampilan inquiry, menggunakan pembelajaran kooperatif; 
2. Melatih siswa tentang strategi pemecahan masala; pemberian alas an yang mendalam, metakognisi, berpikir kritis, dan berpikir secara sistem; dan

3. Menjadi perantara proses penguasaan informasi; meneliti lingkungan informasi, mengakses sumber informasi yang beragam, dan mengadakan koneksi. 


\section{REFERENSI}

Anis, M. Z. A (2020). Sejarah Bukan Warisan Melainkan Pembelajaran.

Anis, M. Z. A. (2017).Pendidikan Sejarah, Patriotisme \& Karakter Bangsa MalaysiaIndonesia."

Anis, M. Z. A. (2016). Sejarah, Kesadaran Sejarah dan Pupusnya Identitas Nasional. Program Studi Pendidikan Sejarah FKIP Universitas Lambung Mangkurat.

Anis, M. Z. A. ." (2016). "Sejarah, Kesadaran Sejarah dan Pupusnya Identitas Nasional."

Handayani dan Sapir, (2009) Efektifitas Penerapan Model Pembelajaran Berbasis Masalah (Problem Based Learning) dan Pembelajaran Kooperatif (Cooperative Learning) Tipe Jigsaw untuk Meningkatkan Aktivitas Belajar, Hasil Belajar dan Respon Belajar Siswa pada Mata Pelajaran Ekonomi di SMA Negeri 2 Malang

Rusman, (2010) Model-Model Pembelajaran Mengembangkan Profesianalisme Guru

Sugiarti dan Kurniawati, (2019) PENERAPAN MEDIA AJAR DIGITAL BERBASIS 4C ( COMMUNICATION, COLLABORATION, CRITICAL THINKING AND PROBLEM SOLVING, DAN CREATIVITY AND INNOVATION) DALAM MENGHADAPI REVOLUSI INDUSTRI 4.0 DI KALANGAN GURU YAYASAN MANDIRI BERSEMI

Sari dan Rihadi, (2014) pembelajaran berbasis masalah untuk meningkatkan kemampuan komunikasi matematika siswa sekolah menenegah pertama 